\title{
Legitimation Crises in Premodern Worlds
}

\author{
Peter N. Peregrine \\ Anthropology Department \\ Lawrence University \\ Appleton, WI 54911 \\ peter.n.peregrine@lawrence.edu \\ Copyright 1996 by Peter N. Peregrine.
}

v. $7 / 8 / 96$

\begin{abstract}
Scholars employing world-system theory have tended to examine how world-system develop and expand, while few have addressed the fragmentation or collapse of worldsystems. This paper explores the conditions of world-system collapse using Habermas's concept of legitimation crisis as a starting point. The paper posits that legitimation crises are a recurring problem in world-systems and have led to collapse in a number of cases. Prehistoric North American and Pacific world-systems are used as examples.
\end{abstract}

\section{Introduction}

If the world-system perspective is indeed rooted in the proposition that "everything is process," as Wallerstein stated in his seminal 1974 article, then collapse (which I define following Tainter [1988: 4] as a significant loss of an established level of sociopolitical complexity) should be one of the processes we are interested in. In fact, our work should equally weigh rise and collapse, centralization and decentralization, growth and decline, viewing them as alternate outcomes of a singular process of world-system operation, rather than as polar opposites--one occurring when a world-system is functioning well, the other when it has broken down. Despite this, world-systems analyses have rarely focused on collapse, even though world-systems theory should be particularly useful for investigating collapse because crisis in one part of the system could, due to the interdependency of polities in the world-system, lead to crisis in the system as a whole--a process that seems common (Tainter 1988).

Existing theories of collapse tend to assume environmental crises or failures in the subsistence economy are the basis of collapse, and often this assumption is not clearly articulated. A perusal of Tainter's (1988: 39-90) comprehensive summary of these theories will demonstrate that many discussions of collapse, while not explicitly concerned with the

[Page 1]

Journal of World-Systems Research 
environment or subsistence economy, implicitly describe collapse in terms of environmental degradation, overpopulation, increasingly marginal returns on the energy put into complexity (Tainter's own view--1988: 118-123), or the like. In short, these theories implicitly link collapse to crisis in the subsistence economy; to a crisis in the ability of individuals to maintain life processes (also see the papers in Yoffee and Cowgill 1988). In contrast I suggest collapse is equally likely to stem from a crisis in social reproduction--from an inability of individuals to sustain themselves socially-- and not from individuals' inability to sustain themselves physically.

This paper considers the collapse of world-systems and posits a theory emphasizing social reproduction to explain why repeated patterns of rise and decline appear so common (Anderson 1994; Blanton et al. 1996). The theory is rooted in the work of Jurgen Habermas, a controversial figure whose sociological writings are difficult, uneven, and often flawed (see, for example, Bernstein 1985), but one whose insights into the workings of the Capitalist world-system, and, by extension, other, premodern worldsystems, have been overlooked. To be fair, both to Habermas and to world-systems theorists, Habermas has never embraced the world-systems perspective and has never talked about the Capitalist "world-system." However, Habermas's work on the culture of late Capitalism is explicitly cybernetic in approach, and Habermas views Capitalism as an holistic system of interdependent polities much as Wallerstein does. Habermas lacks the specific theories of world-system process, of geographic differentiation and competition, of unequal exchange and uneven development, but his ideas are, I suggest, amenable to the world-system perspective, and can easily be incorporated into it.

The primary distinction between Habermas's perspective and a strictly world-systems one is that Habermas views the economic, political, and social subsystems of Capitalism as having equal importance. In other words, the economy is not seen to be the only, or even the most important, force in the system's operation. Indeed Habermas (1973) argues that these three subsystems are so intertwined that they cannot be reasonably separated. His insistence that the political and social be given equal weight to the economic is a product both of his philosophy of "communicative action," which envisions all social forms as created through communication between "rational" individuals, and his understanding of how the Capitalist system operates (see Habermas 1976).

Figure 1 is a diagram of Habermas's (1973) conception of the Capitalist system. On the far left is the economic system, the privately-owned enterprises which produce goods and

[Page 2]

Journal of World-Systems Research

services for profit. The arrows going to and from it show how it is aided by the political system, which develops laws and policies beneficial to economic interests, and which works with other polities to maintain favorable conditions for growth. In this way, the political system helps to steer the economic system to maximum performance for private, 


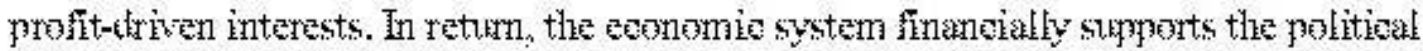
system, whide ounnot maintain itself otherwise sine it prokthes nothing beyond steering

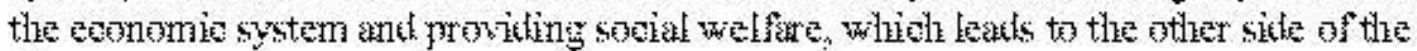
thiegram.

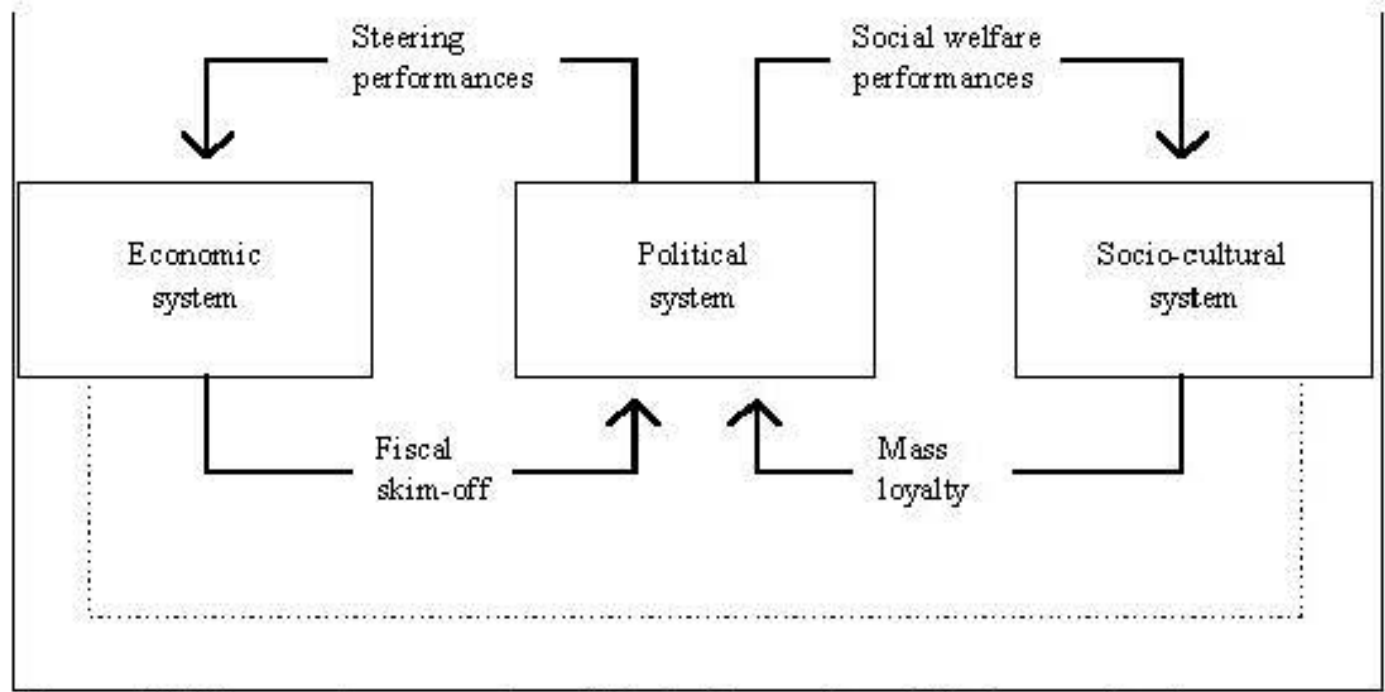

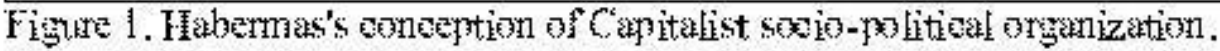

The right sike of Finge 1 shows the socio-enltural system, basically the tratitions, beliefs, norms, walkes, expectations, and the like, which are shate by membars of the

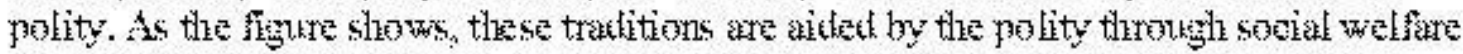

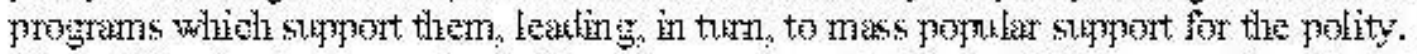

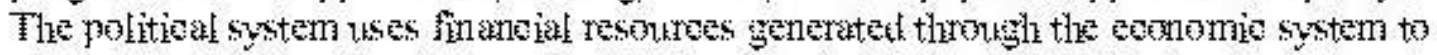

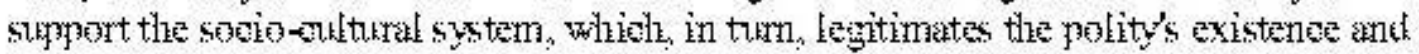
right to govern, i.e. its right to oreate and implement laws and poliejes beneficial to the maximum operation of the eonnmie system. This interkepenteney is the basis of Habermas's view of C apitalist soejeties ank the basis of lis ooneention of legitimation crises.

Becanse the three systems are tightly interiependent, a erisis in any one of them may leak to a systemie orisis of the whole. Howerer, Itabermas (1973) suggests that the we ak point in the system is in the "mass loyalty" arrow leathing from the soeiv-enltural system to the

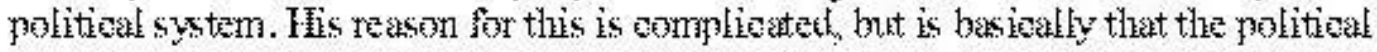
sustem an ontrol exerything exeept peonle's "rational" minks, and orises in any wart of

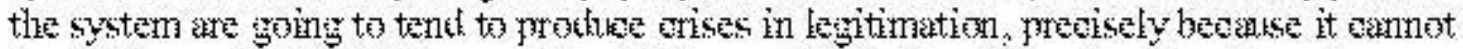
be reaklily wontrollet. Habermas's insight is onkeial for the tisenssion of oollagse in worlek-systems. What Tabermas arghes is that an environmental oakamity or orisis in the subsisten ee eonomy is not a neessary, or even common, frecontlition for collapse; rather, a disis in the soele-cultural system, a legitimation orisis, is a more likely souree of politioal oollapse.

Chearly there are sme unique feathes of Cianitalism that both illuminate and oonfise

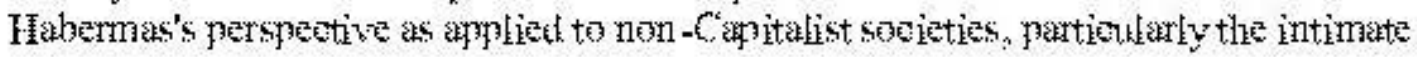




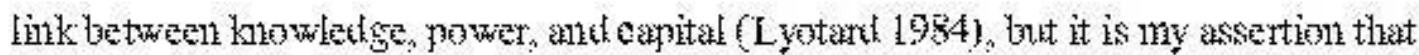
the interrelated system rataenmas proposes for Copitalist soejeties exists in all politioally

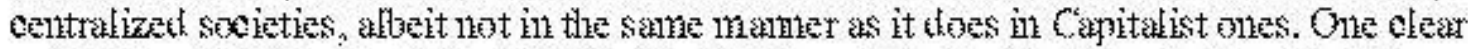

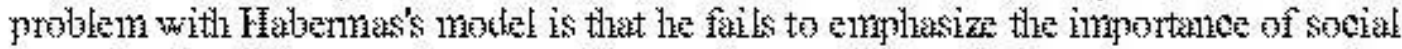

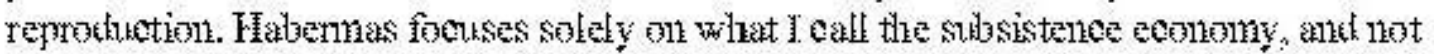
छll

\section{[Page i]}

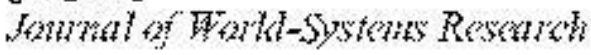

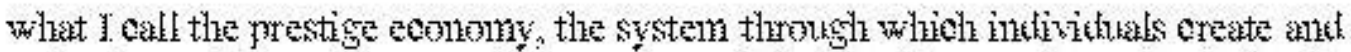

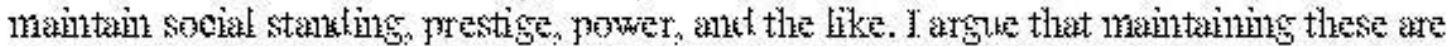

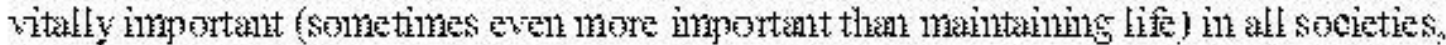
even Capitalist ones.

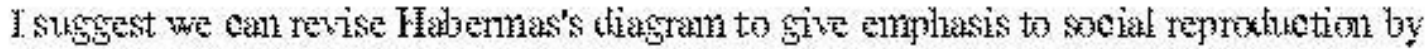
replacing the "econmie system" with "prestige-s sstem", the "politieal system" with

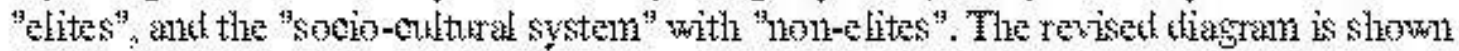
in Figre 2.

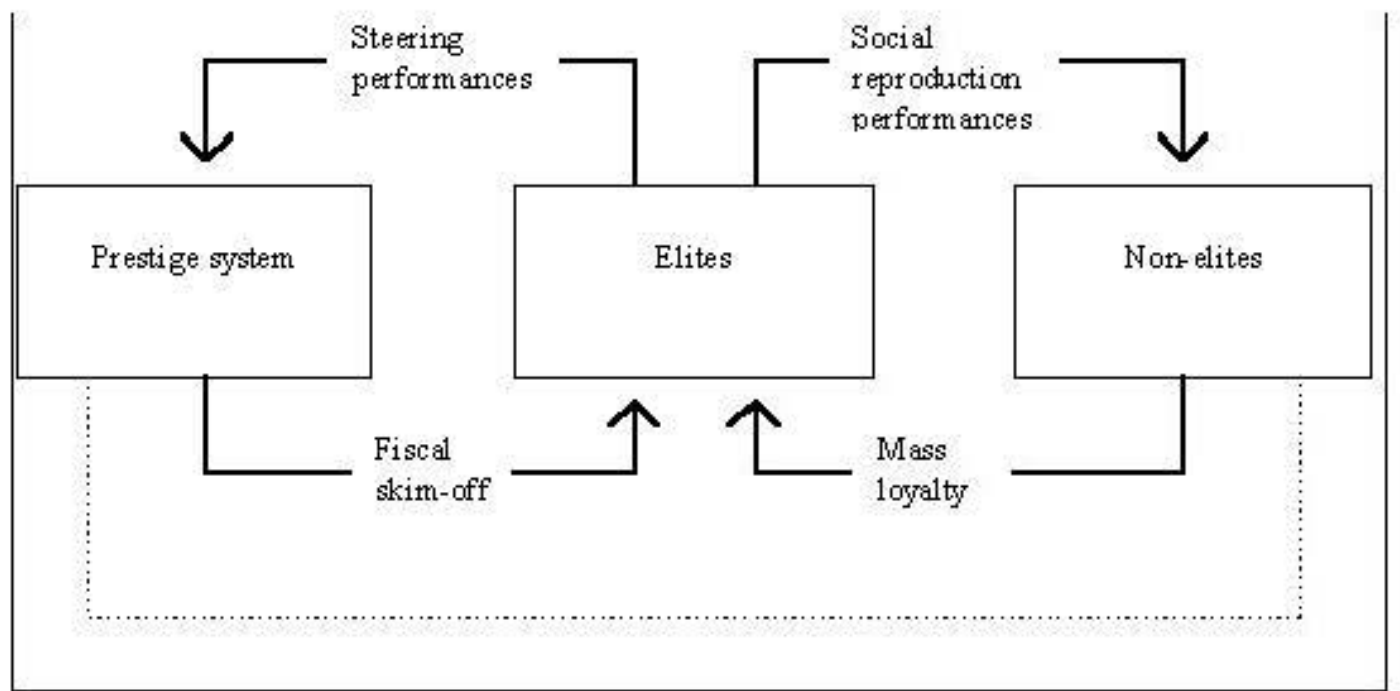

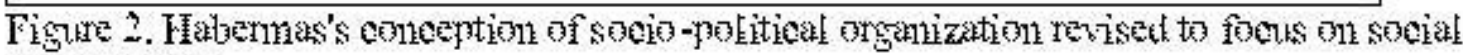
repratiketion.

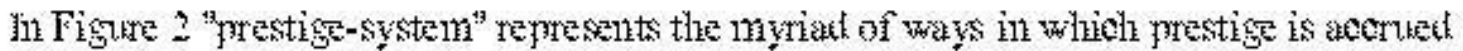

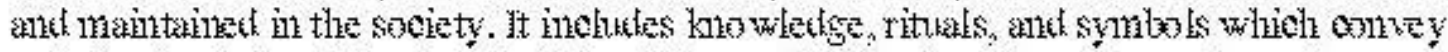

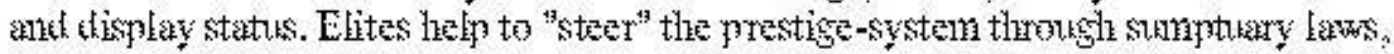

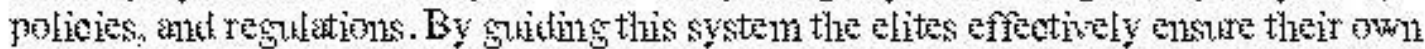

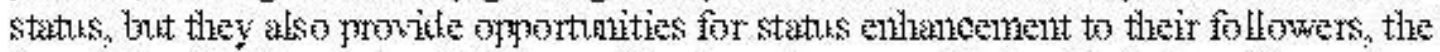

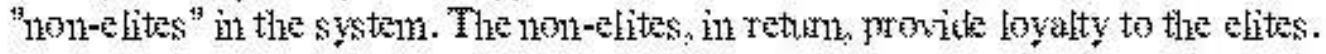


The system works similar to the way Habermas sees Capitalism operating, except that profit here is in terms of prestige rather than of capital. Also, there are either no individuals who uniquely control the economic sector (i.e., who own the "means of production"), or if there are, they are the same individuals as the elites who run the political sector. In other words, elite manipulation is not focused on production to sustain life, but rather on sustaining systems of social reproduction. An example may help illustrate this idea.

\section{The Tongan Polity}

The Tongan archipelago is located in the Pacific Ocean some 2000 miles east of Australia and 600 miles southeast of Fiji. It consists of about 160 islands strung out over 200 miles on a roughly northeast-southwest axis (Kirch 1984: 217). The population in the 1920s was about 25,000 , most of whom lived on the three large islands of the archipelago (Gifford 1929: 4): Tongatabu (100 square miles); Haapai (20 square miles); and Vavau (46 square

\section{[Page 4]}

Journal of World-Systems Research

miles), and most of the land area was given over to fields and stands of yam, taro, sweet potato, breadfruit, plantains, and coconuts (Goldman 1970: 281).

At the time of first contact with Europeans (ca. 1643), Tonga had a dual political structure, with two major leaders: the Tu'i Tonga, who was considered divine, and was the link between humans and deities; and the Tu'i Kanokupolu, who answered only to the Tu'i Tonga, and was responsible for secular concerns in the chiefdom (Kirch 1984: 224 25). As described by Basil Thompson (quoted in Kirch 1984: 225):

[the spiritual king]-the Tu'i Tonga--was lord of the soil, and enjoyed divine honours in virtue of his immortal origin... The temporal king--the Tu'i Kanokubolu--was the irresponsible sovereign of the people, wielding absolute power of life and death over his subjects, and was charged with the burden of the civil government and the ordering of the tribute due to the gods and their earthly representative, the Tu'i Tonga.

Both the Tu'i Tonga and the Tu'i Kanokupolu had a group of four chiefs and attendants who were known as falefa, and served as the Tu'i's courtiers (Kirch 1984: 230-31).

Subservient to the Tu'i Kanokupolu's falefa were a number of local, landholding chiefs, or eiki, their attendants, or matapule. Subservient to the landholding chiefs were lesser chiefs, also called matapule, hereditary titled craftsmen, or tohunga, and finally commoners, or tua (Kirch 1984: 231-32).

Irving Goldman (1970: 314-15) offers an interesting outline of the Tongan political structure through what he describes as four segments of political hierarchy. The first 
segment refers to the Tu'i Tonga and Tu'i Kanokupolu, who maintain ultimate power in Tonga. The second segment refers to the chiefs of landholding lineages, who "were in virtually all respects sovereign in their own jurisdiction. Each major lineage was a replica of the entire administration" (Goldman 1970:315). The third segment refers to sub-chiefs of the major landholding lineages, "and for its most part a replica in most respects of the major branch, dependent on the major as the major was on the Tu'i Tonga or his representatives" (Goldman 1970: 315). Finally, the fourth segment refers to the patrilocal household. Goldman (1970: 315$)$ tells us that "A hierarchy of successive dependenc ies was the ancient Tongan scheme," and at the base was the patrilocal household.

The organization of these patrilocal households was reproduced in the political hierarchy of Tonga. Generation and sex were the basis of rank within the family, and rank was the basis of political power: "The first-born son took the title, the social position, and

[Page 5]

Journal of World-Systems Research

the leadership in the family" (Goldman 1970: 289). Although sisters outranked brothers in formal honor, females did not hold political office or power in Tonga, and the head of the family was the eldest male, and was succeeded by his younger brother or eldest child (Gifford 1929: 20, 290).

This patrilineal ranking between fathers and sons, older brothers and younger brothers, was reproduced in the political hierarchy of Tonga, and formed a base for legitimating power. As Gifford (1929: 19) explains:

Ranking of individuals within the Tongan family...is the key to the organization of Tongan society in every stratum. From the bottom to top and from top to bottom of the social ladder one general scheme of family organization prevails. As the Tu'i Tonga is eiki (chief) to his younger brothers, so in every Tongan family the older brother is chief to his younger brothers...Relatively speaking, in every household there are chiefs and commoners.

The reproduction of this system of generational ranking throughout the Tongan political hierarchy is obvious in the nature of political relationships:

Titled chiefs stand in certain fixed relationship to one another. Thus Ata, the "dean" of the Tongan chiefs is "grandfather" (kui) to all of the chiefs in the kingdom, except the Haa Ngata Motua chiefs, to whom he is "older brother" (taokete)...These are not true relationships, even though conside red as extensions of terms for lineal relatives to collateral relatives. They are, if anything, mirrors of the relationships in which the first title bearers stood to one another (Gifford 1929: 128).

\section{Primogeniture, Marriage, and Power in Tonga}


Power in Tonga was held, at all levels, by social elders. In the family, the eldest member served as head. Lineage chiefs were considered the socially eldest in the lineage. Higher chiefs were "grandfather" or "older brother" to lesser chiefs, and all the chiefs were descended from the Tu'i Tonga. The power elders had over subordinates was derived, in part, from their control of prestige-goods.

[Page 6]

Journal of World-Systems Research

Prestige-goods were a vital part of Tongan marriage alliances, and hence, were vital to an individual's ability to marry well. Prestige-goods in Tonga were controlled at the highest level, by the Tu'i Tonga and the Tu'i Kanokupolu. They flowed down the levels of hierarchy, and were a central force in maintaining hierarchical relationships. Kirch (1984: 238) makes this point very clear:

Tonga stands unique among the indigenous Polynesian chiefdoms for its extensive and regular long-distance exchange relations with societies beyond its own geographic and political borders. This long-distance exchange had political consequences which were far greater than any immediate, utilitarian gain due to the importation of exotic material items. Long-distance exchange of chiefly spouses as well as of material items was fundamentally a political strategy, and played a vital role in binding the core islands and outliers to the central polity.

Marriage payments, and the social prestige that went along with them, were described in detail by Gifford (1929: 192-93):

Preceding the day of the beginning of the [wedding] ceremony, the fathers of the bride and groom each assembled a large gift, including tapa, mats, and oil. The particular father notified all his relatives and all his wife's relatives of the coming ceremony and asked for contributions...In distributing the presents, the bridegroom's father or other official representative of his people... had in mind what each person had donated toward the present that had been given to the bride's people, and each got his original gift returned in double quantity. In accomplishing this return, the distributor often stripped his own house of all its material property. If he should fail to complete the traditional remuneration to all concerned, his unmarried sons and daughters and the progeny of his married children lost face and might consequently fail to contract desirable marriages...A similar distribution was made of the presents of the bridegroom's people to the bride's people.

If there was great inequality in the size of the wedding gifts, the group making the smaller donation was shamed and lost social prestige to the other group.

In Tongan society marriage with an eldest son or daughter virtually determined the status of one's children, grandchildren, and lineage. As Gifford $(1929: 20,112)$ explains: 
a commoner is an individual who by virtue of descent through a series of younger brothers has in the course of generations become further and further removed from the patriarchal head

[Page 7]

Journal of World-Systems Research

of the family, as represented by a contimous line of successive eldest sons...The commoner is the man in a line of descent that gets further and further from the head of the lineage with each succeeding generation.

A Tongan's social position was relatively fixed. Although there was some room for movement, the status of his lineage, his parents, and his birth-order, all more-or-less determined his status. The potential status of his children, his grandchildren, and, in the long run his lineage, were, however, dependent upon marriages. By continuously "marrying up" in the Tongan hierarchy, an individual's children, grandchildren, and lineage could slowly increase their status. Just as a commoner was the product of a long line of younger brothers, so a chief was the product of a long line of elder siblings. The goal of Tongan marriage was to keep one's relatives marrying elders.

There was tremendous pressure to meet marriage payments and to make them extravagant, so that one's descendants would not lose rank through a poor marriage. Since prestige-goods were needed for these payments, and the payments made possible marriage with a socially elder individual, those who controlled prestige-goods controlled individuals' abilities to socially reproduce themselves, as Kirch (1984: 241) makes clear:

Kinship alliances linked the paramount lines with those of the local nuling chiefs in the core islands and outliers. Such alliances were confirmed by marriage relations, for which exotic prestige goods were vital. In turn, the outlying islands affirmed their inferior status and loyalty to the hau [Tu'i Kanokupolu] and the Tu'i Tonga through the tribute of the 'inasi. Thus within the chiefdom there was a circular flow of goods, tribute inwards towards the paramounts, prestige goods outwards to the local chiefs. Mo nopolization of the sources of prestige goods by the paramounts helped to secure their power over the system as a whole.

Tongan social elites controlled prestige-goods needed by their subordinates to socially reproduce themselves. A dependency relationship thereby existed between elders and subordinates, that served to keep the elders in power and able to control younger members of society. This relationship is diagrammed in Figure 3. 


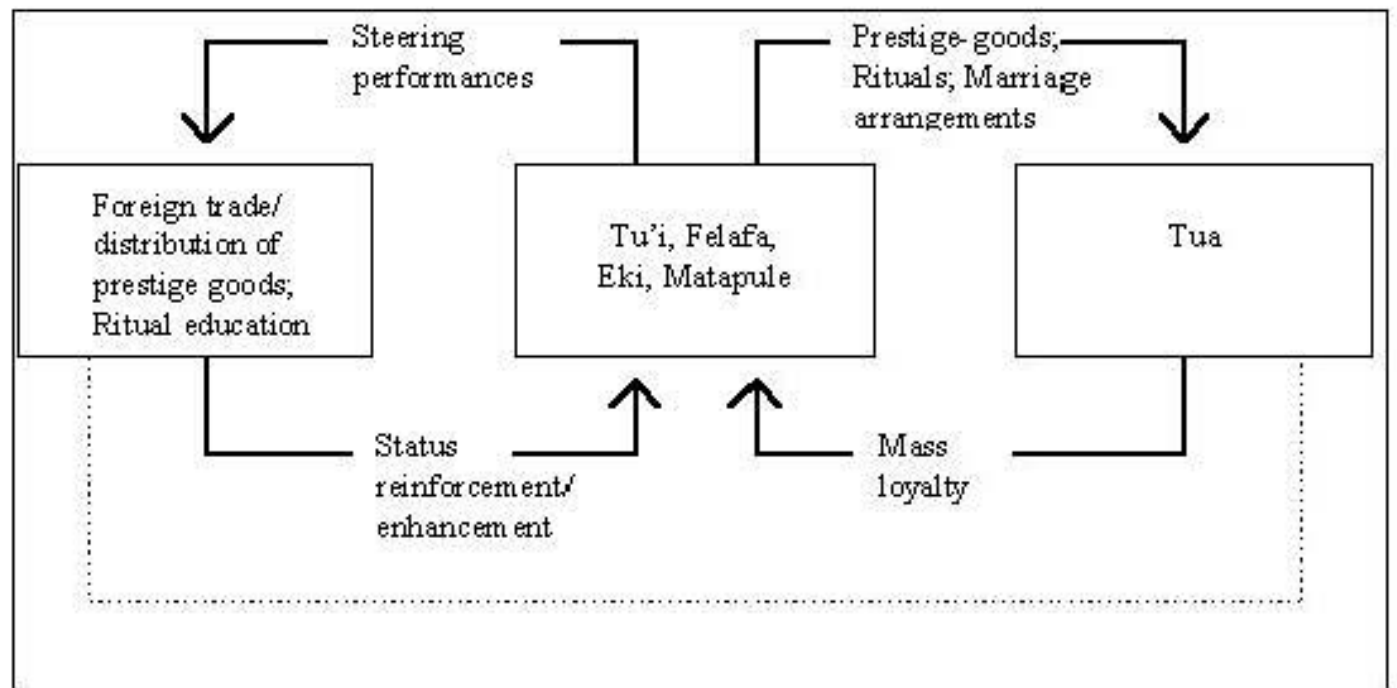

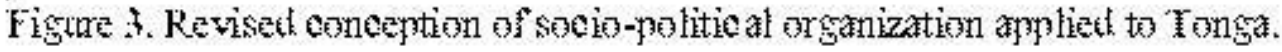

At the eenter of Figure i are the Tongan elites, the wus and the other nobility. Through

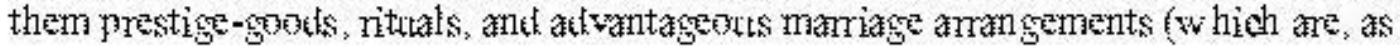

[Page s]

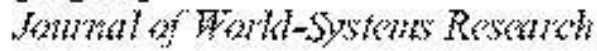

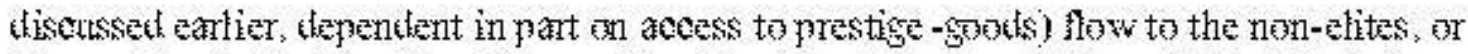

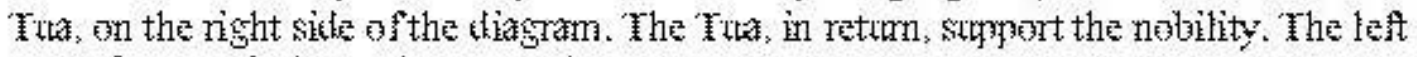
sikfe of Figrte I shows the external trate in prestige-goods and, to some extent, marriage

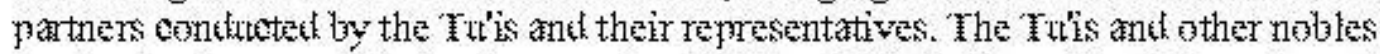
onntuet and manage this trate, as well as the loeal distribution of trated gowats, and by thoing so enhanee their own noble status. In atklition, the nebles ontrol ritual knowledge and it dissemination--another arena for status enhaneement and reinforement.

Clearly a weak point in this system is the foreign trate in mestige-gobds. If troken this weak point coukl easily leat to a legitimation ensis. If trate were eut of an impertant avente for both status enhaneement and, more importantly, the maintenanee of mass loyalty woukl be severek. If the netbility oankl not fink another avente to reinforce mass

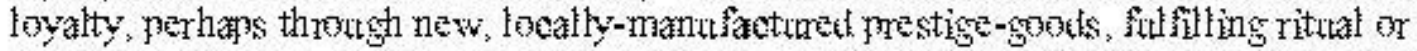

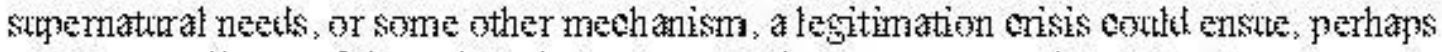
causing a collapse of the politieal strueture. In the Tongan ease this thet not ceerr; however, dtung a period of eivil war among rival ou'is and their followers, ties with Exropeans that frovided status-enh aneing trake objects and sumernatural knowledge (or Christianity) were aetively sounht by the ontenting elites (see, for example, Thompson

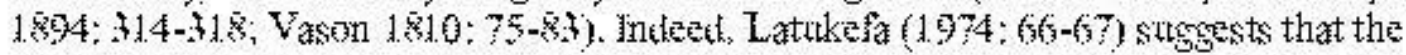

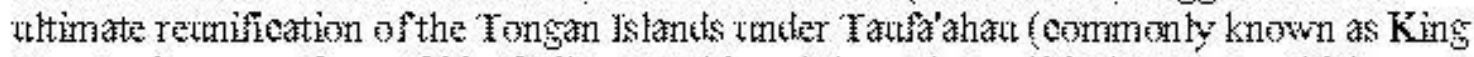
George, in power from $1.83-1.89$ ) was achevel through a politieal stratesy which 
included his open acceptance of Christianity and support for new sources of status and power afforded by Christian missionaries (also see Thompson 1894: 346-352).

There are many cases which end differently; that is, in legitimation crisis and collapse. One such case, I suggest, is the prehistoric Moundville polity of west-central Alabama.

\section{The Moundville Polity}

The Moundville polity represents one of the pinnacles of cultural evolution in eastern North America. Moundville is part of the larger Mississippian cultural system, which evolved beginning about A.D. 900 in the Mississippi River valley and its major tributaries. The Mississippians developed large population centers, traded with peoples as distant as the Florida Gulf coast and the Great Plains, and constructed the largest preColumbian structures north of Mexico. Mississippian influence spread across eastern North America in the following century, and by A.D. 1100 it was the predominant culture across the Southeast and

[Page 9]

Journal of World-Systems Research

had fundamentally influenced peoples in the Ohio River region, in the northern Mississippi valley, and west into Iowa, Kansas, and Oklahoma. This influence continued even as some of the earliest Mississippian polities, including Moundville, declined beginning about A.D. 1200. Although altered by time and restricted in their geographical range, Mississippian-like ways of life still existed in parts of the Southeast and the lower Mississippi River valley when Europeans first entered the North American continent.

The Moundville polity was located on the Black Warrior River in west-central Alabama, and was inhabited from ca. A.D. 1000 to ca. A.D. 1450. The site itself consists of 20 mounds covering an area of more than 40 hectares. The mounds surrounded a large plaza that formed the political or religious center for the surrounding region. Residential areas surrounded this plaza-mound complex, and the entire site was surrounded by a defensive palisade. At its peak, 3,000 or more people may have lived within the palisade at Moundville. Surrounding Moundville are a series of smaller villages and hamlets linked to the larger polity, and likely provided both material goods and labor to it (Welch 1991).

Socio-political organization in the Moundville polity was hierarchical, elites having clearly differential access to food resources and exotic goods (Welch 1991; Powell 1988), and is most readily classified as a chiefdom (Peebles and Kus 1977). Welch (1991) tested four models of chiefdom political economy (redistribution, mobilization, tributary, and prestige goods) against the archaeological record of the Moundville polity. He found that the prestige goods model best fits the archacological data. This type of political economy is quite similar to that described for Tonga, with lineage-based chiefs maintaining control over status-displaying or enhancing goods obtained through foreign trade. They provide 
some of these goods to followers in return for their support, both political and material. Hence Moundville's elites would have been deeply involved in foreign trade and the production of goods for foreign trade, and in the creation and maintenance of symbol systems and ritual behaviors that required prestige goods (also see Peregrine 1992, 1995).2

Pauketat (1994) recently examined the Cahokia polity, a contemporary of the Moundville polity located in East St. Louis, Illinois, to explore the ideology which sustained political hierarchy. He argued that Cahokian ideology initially was based on a patron-client relationship which developed through time into a divine-secular relationship. Cahokian chiefs initially legitimated their authority through their generosity with material goods and by supporting craft specialists, but reinforced it through external alliances and claims to esoteric knowledge of distant peoples, places, technologies, and behaviors, and, ultimately, of the supernatural. A similar situation was likely present in the Moundville polity.

[Page 10]

Journal of World-Systems Research

Political power in the Moundville polity, then, appears to have been based upon the ability to control prestige-goods, legitimated in part through a lineage structure (Anderson 1994; Knight 1990; Peregrine 1992, 1995; Welch 1991), but also through differential access to both external allies and supernatural power (Pauketat 1994). In this way, the Moundville polity is quite similar to Tonga. Like Tonga, the organization of settlement suggests that a hierarchy of chiefs was present in the Moundville polity, with the pre-eminent chief located at the major center of Moundville itself, and lower level chiefs located at minor centers and in outlying hamlets (Peebles and Kus 1977; Steponaitis 1978). The political hierarchy itself was probably organized like a lineage (Knight 1990), with individuals in each level both superior and socially "elder" to individuals in levels below them (DePratter 1983: 100-10). At the lowest level in the political hierarchy were localized lineages, with elder males as their heads.

In this way, the schematic diagram of the Moundville polity in terms of Habermas's model presented in Figure 4 is very similar to that for Tonga. Chiefs, in the center, distributed prestige-goods (and likely ritual knowledge) to their followers, who in return supported the chiefs through their loyalty. Chiefs also engaged in long-distance trade for prestige-goods, which they distributed internally, both reinforcing their status and allowing them the opportunity to enhance the status of followers. 


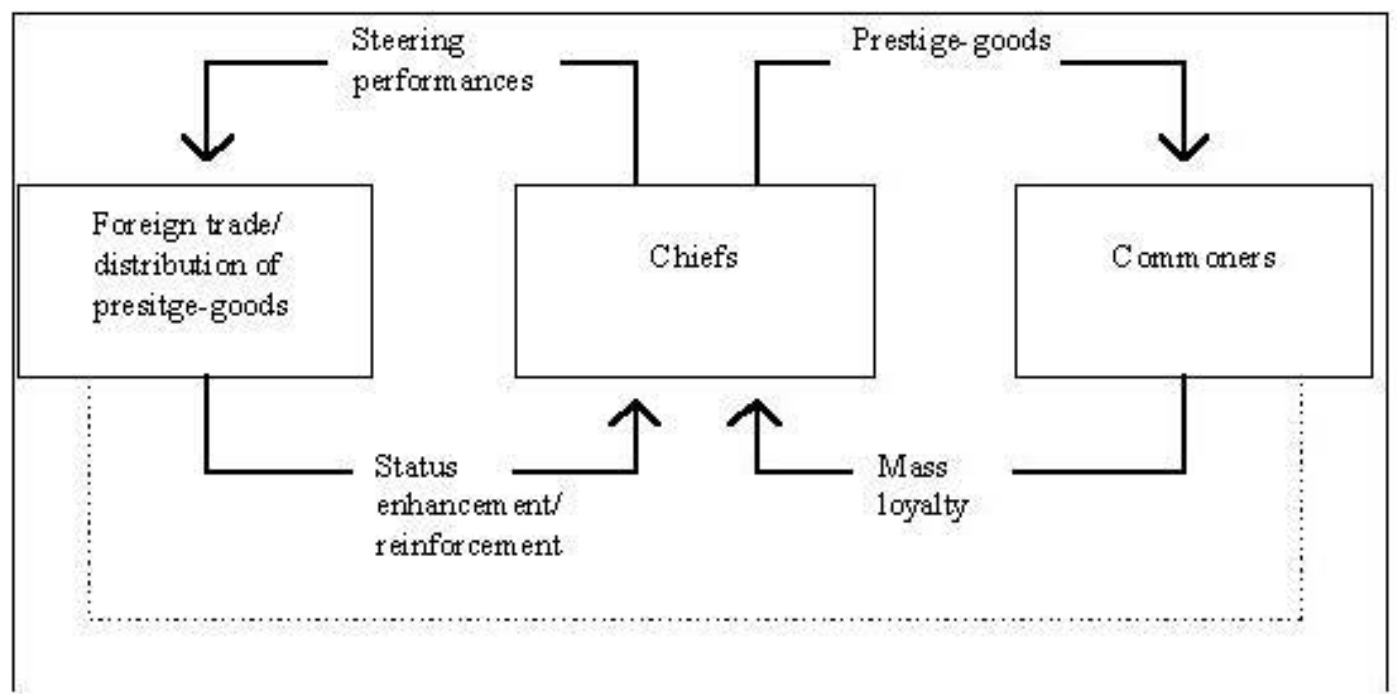

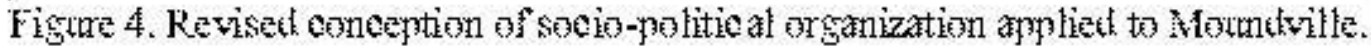

\section{Collapse of the Moundville Polity}

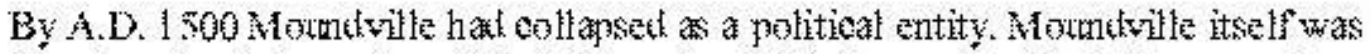

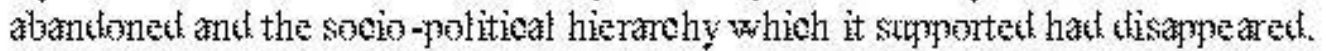

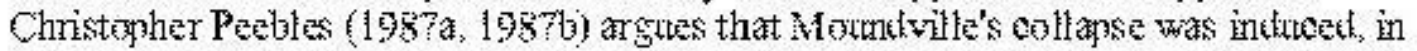
pat, by a oonstriction of trate in yrestige-gooks. Data from the wormetille site and the

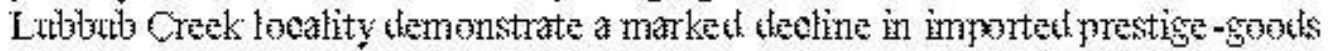
beginning about A.D. 1400 (Pozbles 1987a, 1987 ). Figne 5 presents the data this argument is based an. The roman numeras on the $X$-axis refer to the arehaeological

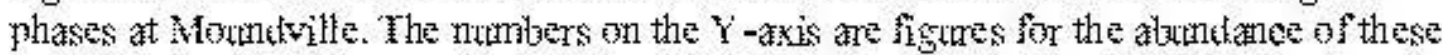
goods in dated burrats, standartized by dividing the number of goods by the number of dated burials per phase (see Steponatis 199 ).

[Pagge 11]

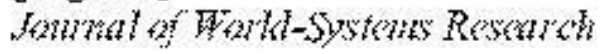

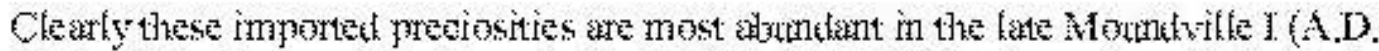

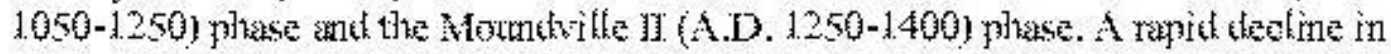

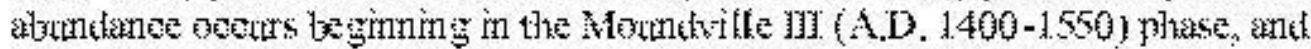

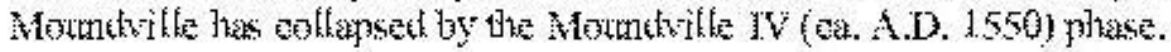




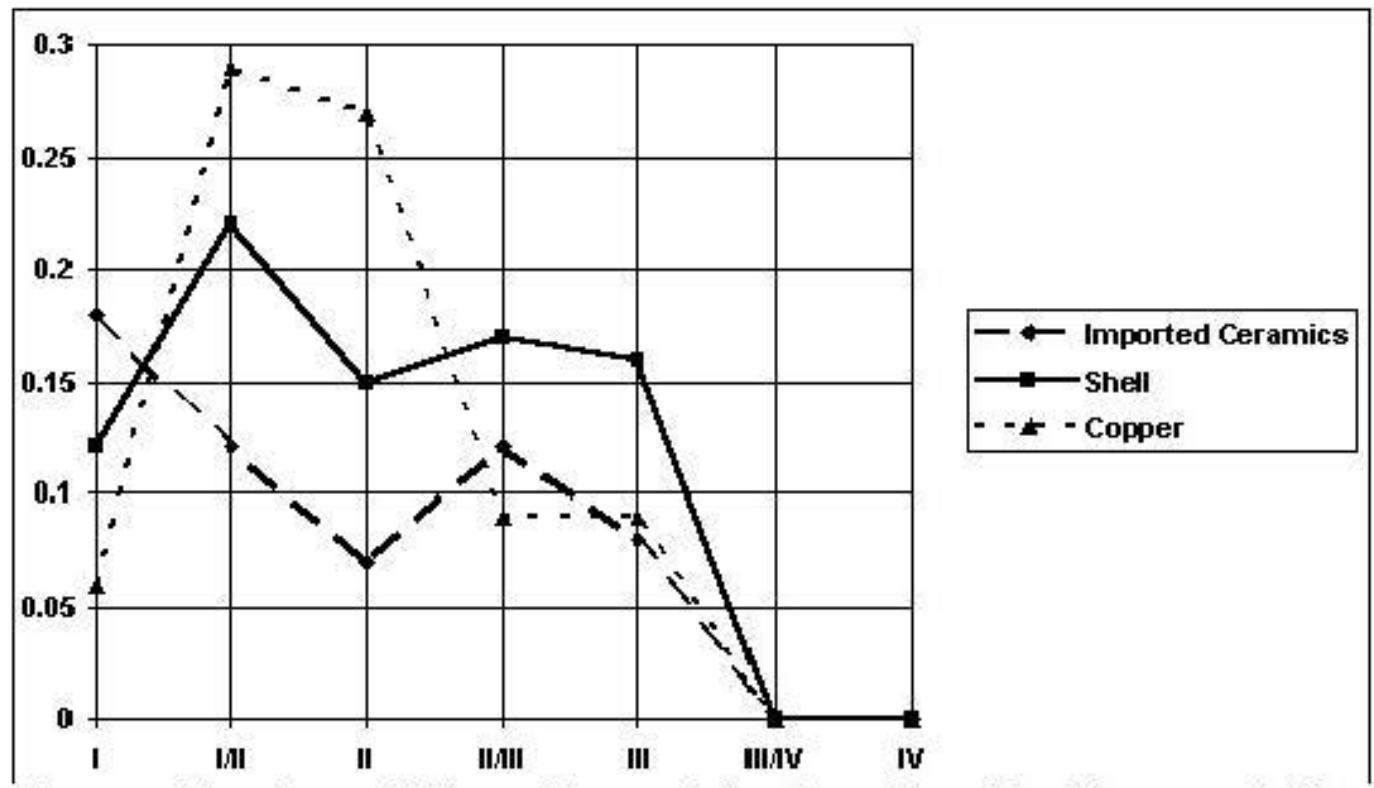

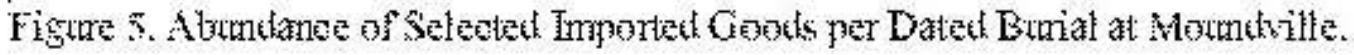

Path Weldi (1991: 194) explains the effed this dedine in acess to prestige-foods might have hat on the Mouthitille polity: "if a lange number of legitimizing smbels are persistently or chronically wanalable, the system of statuse is likely to break town." Linking Weloh's statement to the thagram presentel in Figrte 4 gives ths a dear pietre of an ensting oollapse. On the left site of the thagram, the clief's steering of trate in

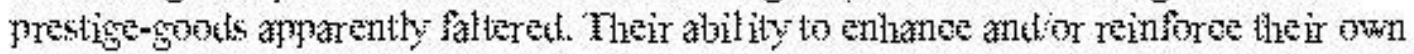
status is thereby atwersely afeded. More signifoantly, their ability to distribute yrestige-

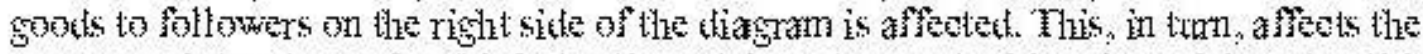

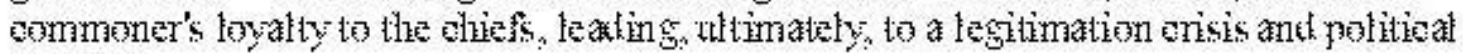
vollatse.

What wathl this collagse look like? I stggest it wotht look as if the top level of the political hierarely was simply att of -as if the ommoners simply "hoted with their feet" and organizet theme hes at a lower level of politioal integration. One wathlit net exped

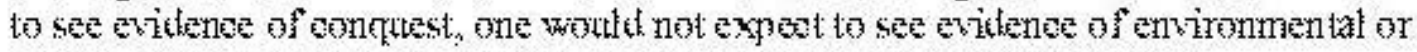

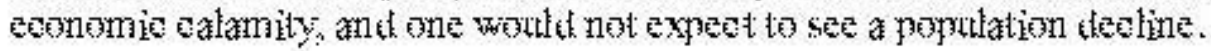

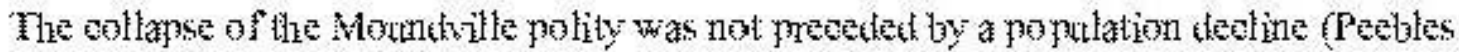
1.987a: 9). There is no bitenee of onntrest or of environmental oatastrophe. What does

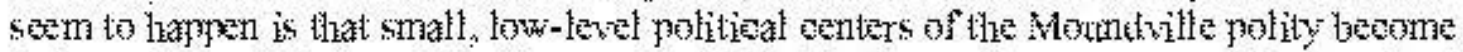
intepentent poltival entities (Stepenatis 1.991.). Settement becmes more tispersed and

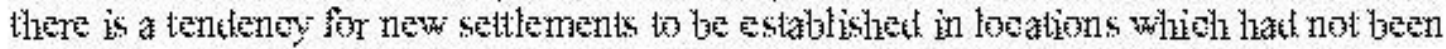

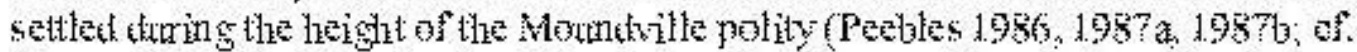
Steponatis 1991: 202). In short the pioture that emerges fists exadty with what one watkl exped from a oollapse the to a legitimation orisis.

\section{Conclusions}


Collapse is a fact of life for complex society, and while collapse may stem from environmental and economic problems, the point I hope I have made here is that an equally

[Page 12]

Journal of World-Systems Research

compelling source of crisis is the system of prestige which legitimates and supports the elite groups in the society. The prestige system is not epiphenomenal to the economic system, but a separate and essential element of socio-political organization in all complex societies. Unfortunately scholars have tended to downplay this part of society and to emphasize the subsistence economy.

In this paper I have presented one case of collapse in which subsistence, population, and the environment seem to have had little influence. I suggest the Moundville polity collapsed through a legitimation crisis stemming from a constriction of the inter-regional trade in prestige-goods. The Moundville polity functioned as a prestige-good system, in which political authority in part rested on controlling access to objects required for social reproduction and status display. When those in positions of authority found it impossible to maintain regular access to these goods, a crisis ensued which had systemic consequences. While this paper offers no explanation of why trade in these goods became constricted (but see Peebles 1987a, 1987b for some ideas), this does not discount the important conclusion that collapse, in this case, was apparently not related to the subsistence economy or the environment; rather, it was a consequence of a failure in the prestige-economy and a transformation of longstanding patterns of inter-regional interaction. It is the concept of legitimation crises as a potent force in social change which I hope I have successfully conveyed in this paper, but another, perhaps more subtle point I hope I have made is that crisis and collapse have many sources, and we must be willing to look beyond the subsistence economy if we hope to understand them.

Legitimation crises, too, have potentially many sources, and it would be myopic to focus on transformations of inter-regional interactions as the sole one. Some areas that might prove valuable to investigate include the effect of new ideologies, the decay of existing ideologies, and conflicts stemming from succession to office. The effect of new ideologies on the legitimation of an existing political order has already been seen in the case of Tonga, where King George purposely used Christianity as an alternative ideology to separate himself from rival political figures--a strategy that has been repeated in many parts of the world (see, for example, Ekholm (1972) on the Kongo Kingdom of west Africa and Axtell (1985) on various Indian polities of eastern North America).

The decay of existing ideologies as a potent force of cultural change is an idea that has been put forward most lucidly by the literary critic Fredric Jameson (1981; also see Dowling 1984). Jameson argues that in every society there are contradictions and conflicts 
[Page 13]

Joumal of World-Systems Research

which are necessary for the society to continue but which would drive the society apart if they were universally recognized. For this reason, societies develop what Jameson calls "strategies of containment" to mask these underlying conflicts (Jameson 1981: 10, 193, 269-271). These "strategies of containment" are constantly decaying and must be either actively reinforced or, if the decay has spread too far, transformed (Jameson 1981: 97). It seems reasonable to assume that a failure to successfuly transform a decaying "strategy of containment" could be a source of legitimation crisis.

Finally, crises stemming from succession to office have been the stuff of European history for centuries, but they have only recently been explored in non-Western and preModern societies. One of the best pieces of work carrying the problems of succession to office into the ethnographic and archacological literature comes from the archacologist David G. Anderson (1994) who explores chiefdom "cycling," that is, the cyclical consolidation and collapse of polities, in the Savannah River valley of Georgia. Anderson argues that the kin-based political structure of chiefdoms contains an inherent contradition: a chief's closest relatives are generally his strongest supporters and best allies, but they are also his greatest potential rivals and successors. Given this contradiction, rivalry, particularly over succession to office, repeatedly builds to crisis and collapse (Anderson 1994: 330).

These, and other, potential sources of legitimation crisis help to explain the apparent instability of centralized political systems, regardless of their environment, their subsistence, their size. As Tainter (1988: 1) put it: "civilizations are fragile, impermanent things." I suggest, and it is yet another point I hope I have made in this paper, that centralized polities are fragile and impermanent precisely because there are so many potential sources of crisis. Looking only at the envrionment or subsistence economy unnecessarily limits our understanding of these varied sources and we must, I argue, look beyond them if we hope to understand collapse.

\section{Notes}

(1) This paper was originally presented at the 1995 meetings of the American Anthropological Association, and I want to thank Nick Kardulias for inviting me to participate in those meetings. I also want to thank Richard Blanton, Christopher ChaseDunn, John Clark, Gary Feinman, Stephen Kowalewski, and an anonymous reviewer for their substantive comments on this paper. Not all of their ideas were incorporated, but their interest is deeply

[Page 14]

Joumal of World-Systems Research 
appreciated.

(2) As defined in two seminal papers by Friedman and Rowlands (1977) and Frankenstein and Rowlands (1978), prestige-good systems exist when important aspects of political alliance or social reproduction are tied to the consumption or exchange of specific exotic preciosities that can only be obtained through foreign trade. Frankenstein and Rowlands (1978: 76) lucidly explain the economic logic of prestige-good systems:

The specific economic characteristics of a prestige-goods system are dominated by the political advantage gained through exercising control over access to resources that can only be obtained through external trade. However, these are not the resources required for general material well-being or for the manufacture of tools and other utilitarian items. Instead, emphasis is placed on controlling the acquisition of wealth objects needed in social transactions, and the payment of social debts. Groups are linked to each other through the competitive exchange of wealth objects as gifts and feasting in continuous cycles of status rivalry. Descent groups reproduce themselves in opposition to each other as their leaders compete for dominance through differential access to resources and labour power.

In prestige-good systems political power is based on the control and manipulation of exotic, imported preciosities. While elites in all social systems display and maintain their status in part through the control of exotic goods and esoteric knowledge (Frankenstein and Rowlands 1978: 75; Helms 1979), in prestige-good systems these elite symbols are needed by all members of the society for social reproduction (Ekholm 1972; Friedman and Rowlands 1977). Prestige-goods are used in these societies to fund social debts, such as bridewealth payments, initiation and funerary fees, and punitive damages, and elites able to control access to these fungible exotic goods gain political power in direct proportion to the demand for them (Frankenstein and Rowlands 1978: 76).

Because of competion between elites for access to prestige-goods, these systems tend to be highly unstable (Friedman and Rowlands 1977: 228). It seems common for prestigegood systems to repeatedly centralize and collapse, and hence, they provide a uniquely valuable social form for examining these processes (Peregrine 1992). In addition, I have argued that prestige-good systems can be taken as a special-case world-system, and are particularly valuable social forms for examining the rise and demise of world-systems (Peregrine 1991, 1995, 1996).

[Page 15]

Journal of World-Systems Research

\section{References Cited}


Anderson, D, G.

1994 The Savannah River Chiefdoms: Political Change in the Late Prehistoric Southeast.

University of Alabama Press, Tuscaloosa.

Axtell, J,

1985 The Invasion Within: The Contest of Cultures in Colonial North America. Oxford University Press, New York.

Bernstein, R.

1985 Habermas and Modernity. Polity Press, Cambridge.

Blanton, R., S. Kowalewski, G. Feinman, and P. Peregrine

1996 A Dual-Processual Approach to the Evolution of Mesoamerican Civilization.

Current Anthropology 37(1): 1-14.

DePratter, C.

[Page 16]

Journal of World-Systems Research

1983 Late Prehistoric and Early Historic Chiefdoms in the Southeastern United States. Ph.D. dissertation, University of Georgia, Athens. University Microfilms, Ann Arbor.

Dowling, $W$.

1984 Jameson, Althusser, Marx. Cornell University Press, Ithaca, NY.

Ekholm, K.

1972 Power and Prestige: The Rise and Fall of the Kongo Kingdom. Scriv Service, Uppsala, Netherlands.

Frankenstein, S., and M. Rowlands

1978 The Internal Structure and Regional Context of Early Iron Age Society in SouthWestern Germany. Bulletin of the Institute of Archaeology of London 15: 73-112.

Friedman, J, and M. Rowlands 
1977 Notes Towards an Epigenetic Model for the Evolution of "Civilization." In The Evolution of Social Systems, edited by J. Friedman and M. Rowlands, pp. 201-275. Duckworth, London.

Gifford, E.

1929 Tongan Society. Bernice P. Bishop Museum Bulletin No. 61, Honolulu.

[Page 17]

Journal of World-Systems Research

Goldman, I.

1970 Ancient Polynesian Society. University of Chicago Press, Chicago.

Habermas, J.

1973 Legitimation Crisis. Beacon Press, Boston.

1976 Communication and the Evolution of Society. Beacon Press, Boston.

Helms, M.

1979 Ancient Panama: Chiefs in Search of Power. University of Texas Press, Austin.

Jameson, F.

1981 The Political Unconscious. Cornell University Press, Ithaca, NY.

Kirch, P.

1984 The Evolution of the Polynesian Chiefdoms. Cambridge University Press, New York.

Knight, V.

1990 Social Organization and the Evolution of Hierarchy in Southeastern Chiefdoms.

[Page 18]

Journal of World-Systems Research

Journal of Anthropological Archaeology 46: 1-23. 
Latukefu, S.

1974 Church and State in Tonga. Australian National University Press, Canberra.

Lyotard, J.-F.

1984 The Postmodern Condition: A Report on Knowledge. University of Minnesota Press, Minneapolis.

Pauketat, T.

1994 The Ascent of Chiefs: Cahokia and Mississippian Politics in Native North America. University of Alabama Press, Tuscaloosa.

Peebles, C.

1986 Paradise Lost, Strayed, and Stolen: Prehistoric Social Devolution in the Southeast. In The Burden of Being Civilized: An Anthropological Perspective on the Discontents of Civilization, edited by M. Richardson and M. Webb, pp. 24-40. Southern

Anthropological Society Proceedings 18. University of Georgia Press, Athens.

1987a The Rise and Fall of the Mississippian in Western Alabama: The Moundville and Summerville Phases, A.D. 1000 to 1600. Mississippi Archaeology 22(1): 1-31.

1987b Moundville From 1000 to 1500 A.D. As Seen From 1840 to 1985 A.D. In

Chiefdoms in the Americas, edited by R.D. Drennan and C.A. Uribe, pp. 21-41.

University Press of America, Lanham.

[Page 19]

Joumal of World-Systems Research

Peebles, C., and S. Kus

1977 Some Archaeological Correlates of Ranked Societies. American Antiquity 42: 421 448.

Peregrine, $P$.

1991 Prehistoric Chiefdoms on the American Midcontinent: A World-System based on Prestige-Goods. In Core/Periphery Relations in Precapitalist Worlds, edited by C.

Chase-Dunn and T. Hall, pp. 193-211. Westview, Boulder.

1992 Mississippian Evolution: A World-System Perspective. Prehistory Press, Madison. 
1995 Networks of Power: The Mississippian World-System. In Native American Interactions, edited by M. Nassaney and K. Sassaman, pp. 247-265. University of Tennessee Press, Knoxville.

1996 Introduction: World-Systems Theory and Archaeology. In Pre-Cohmbian WorldSystems, edited by P. Peregrine and G. Feinman, pp. 1-13. Prehistory Press, Madison.

Powell, M. L.

1988 Status and Health in Prehistory: A Case Study of the Moundville Chiefdom. Smithsonian Institution Press, Washington, D.C.

Steponaitis, V.

1978 Location Theory and Complex Chiefdoms: A Mississippian Example. In Mississippian Settlement Patterns, edited by B. Smith, pp. 417-454. Academic Press, New York.

1991 Contrasting Patterns of Mississippian Development. In Chiefdoms: Power, Economy, and Ideology edited by T. Earle, pp. 193-228. Cambridge University Press, Cambridge.

[Page 20]

Journal of World-Systems Research

Tainter, J.

1988 The Collapse of Complex Societies. Cambridge University Press, Cambridge.

Thompson, B.

1894 The Diversions of a Prime Minister. William Blackwood and Sons, Edinburgh.

Vason, G.

1810 An Authentic Narrative of Four Years' Residence at Tongataboo . Longman, Hurst, Rees, Orme, Seeley, and Hatchard, London.

Wallerstein, I.

1974 The Rise and Future Demise of the Capitalist World-System: Concepts for Comparative Analysis. Comparative Studies in Society and History 16: 387-415.

Welch, P. 
1991 Moundville's Economy. University of Alabama Press, Tuscaloosa.

Yoffee, N., and G. Cowgill (editors)

1988 The Collapse of Ancient States and Civilizations. University of Arizona Press, Tuscon.

[Page 21]

Journal of World-Systems Research 